Mosque and Reproduction of Arab Identity....

\title{
MOSQUE AND REPRODUCTION OF ARAB IDENTITY IN THE HADRAMI COMMUNITY IN BETAWI
}

\author{
Fajar Syarif ${ }^{a}$, Muhammad Ansor ${ }^{b}$

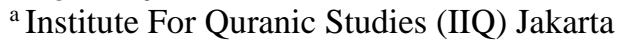 \\ J1. Ir. H. Juanda No. 70, Tangerang Selatan, Indonesia \\ ${ }^{\mathrm{b}}$ Institut Agama Islam Negeri (IAIN) Langsa \\ J1. Meurandeuh Langsa Lama, Langsa, Aceh \\ fajarsyarif@iiq.ac.id, ansor@iainlangsa.ac.id
}

\begin{abstract}
This research aims to analyze historical evidence of the usage of mosques by Arabs in old Jakarta to dominate society. This was shown through that they held a religious position in the mosques. Arabs have a strong influence on the diversity of society but they also try to influence and control the community. The main source used in this study is historical data. The data is interpreted by means of content analysis and using descriptive analytical method with qualitative approach. The conclusion of this research is that mosques are used by Arabs to reproduce Arabic identities.
\end{abstract}

Keywords: Mosque, Arab identity, Hadramy community 


\begin{abstract}
Abstrak
Penelitian ini bertujuan untuk menganalisa bukti sejarah penggunaan masjid oleh pemuka masyarakat beretnis Arab di Betawi tempo dulu, sebagai tempat untuk mengontrol masyarakat. Hal ini dibuktikan bahwa mereka memegang posisi keagamaan di masjid. Orang-orang Arab memiliki pengaruh yang kuat terhadap keberagamaan masyarakat akan tetapi mereka juga berusaha untuk memengaruhi dan menguasai masyarakat. Sumber utama yang digunakan pada penelitian ini adalah data-data sejarah. Data tersebut dibaca dengan cara content analysis (analisis isi) dan menggunakan metode deskriptif analitik dengan pendekatan kualitatif. Kesimpulan dari penelitian ini adalah masjid digunakan oleh orang-orang Arab untuk mereproduksi identitas Arab.
\end{abstract}

Kata Kunci: Mesjid, Identitas Arab, Komunitas Hadrami

\title{
Introduction
}

Mosque is the center of life that can accommodate all forms of social needs and activities. A mosque can be an identity of a community where it was built. (Febriani 2004) This was seen from the hadrami community in building mosques in Betawi as the center of their religious identity. (Anon 1898) For example Habib Abdurrahman bin 'Alwi asy-Syatiri who lived in Betawi in 1737, (van den Berg 1989:130; Kazhim 2013) and Habib Husain bin Abu Bakar Alaidrus who died in 1798 in Luar Batang. (van den Berg 1989:105) Mosques at that time were used for socio-religious identity. (Anon 1898)

Habib Abdurrahman bin 'Alwi Asy-Syatiri who contributed to the spread of Islam in Java from the $16^{\text {th }}$ century to the early $17^{\text {th }}$ century built the al-Mukarramah mosque in Kampung Bandan in 1789. (Algadri 1996; asy-Syatiri 2008; Shahab 2004) Asy-Syatiri found several graves on the beach surrounded by swamps and trees. He then built a small building and a small mosque to help those visited the cemetery. He managed the mosque during his life. (asy-Syatiri 2008: Heiss and Slama 2010) Actually the al-Mukarramah mosque in 
Mosque and Reproduction of Arab Identity....

Kampung Bandan was not the first mosque in the Kampung Bandan area. This is based on data from Adolf Heuken S.J. which stated that there was a mosque built in Kampung Bandan before the alMukarramah mosque namely the al-Anshor mosque on May 18, 1648 on Jalan Pengukiran II, Jakarta. (asy-Syatiri 2008; Heuken 2003)

The establishment of mosques in 1651 was banned by the Dutch colonial government. (Heuken 2003) This rule was ignored by Habib Abdurrahman bin 'Alwi Asy-Syatiri. Meanwhile, Governor General Maetzuyker (1653-1678) said that the establishment of mosques was permitted due to Muslims worship the same God: Allah. (asy-Syatiri 2008; Fadli 2011; Heiss and Slama 2010; Heuken 2003)

Habib Husain bin Abu Bakar Alaidrus came to Betawi in 1746 to spread Islamic lesson. (Fadli 2011; Murti 2016) He was given a plot of land in Luar Batang village, near Sunda Kelapa by the Dutch General and finally a mosque was built on the land in 1736. (Fadli 2011; Jonge 1997) At the mosque, he spread Islam until he died. (Murti 2016) Therefore, both Habib Abdurrahman bin 'Alwi AsySyatiri and Habib Husain bin Abu Bakar Alaidrus opened the steps to create an identity. (Berland, Steingut, and Ko 2014; Mukani 2017)

Habib Husain bin Abu Bakar Alaidrus and Habib Abdurrahman bin 'Alwi Asy-Syatiri according to Ami, affect the condition of individuals from society. (Albernaz 2011) In fact, according to Ward in his research that the event has modified and adjusted Islamic knowledge. This practice continues because it is seen as a part that does not violate anything in fiqh. On the contrary, it finds the right place and continues to be practiced. (van Oudenhoven and Ward 2013) It shows that religious manifestations appear in various 
forms and expressions which are considered to be in accordance with the needs of the community. (Fitri 2012)

Since the two mosques were built, many people came to study Islamic lesson from them. This made VOC authorities worry about their own security. According to Musa Kazhim, Abdurrahman bin 'Alwi Asy-Syatiri was cleric who settled in Betawi in 1737 and was invited by Sunan Pakubuwono II to Surakarta. It turned out that his presence was not liked by the VOC. The tomb of Habib Abdurrahman bin 'Alwi Asy-Syatiri can be seen in Saripan Surakarta (Solo Hajj tomb) until now with a Javanese title named Kanjeng Tumenggung. (van den Berg 1989:130; Kazhim 2013:17) Habib Husain bin Abu Bakar Alaidrus and his students were imprisoned in Glodok (Murti, 2016). He was imprisoned in a prison that was smaller and narrower than his student. But, the wardens were often astonished when they saw Habib Husain bin Abu Bakar Alaidrus leading a prayer with his followers. (Fadli 2011; Murti 2016)

Habib Abdurrahman bin 'Alwi Asy-Syatiri and Habib Husain bin Abu Bakar Alaidrus, according to Ami, affect the condition of individuals from society. (Albernaz 2011) In fact, according to Ward in his research that the event has modified and adjusted Islamic knowledge. This practice continues because it is seen as a part that does not violate anything in fiqh. On the contrary, it finds the right place and continues to be practiced. (van Oudenhoven and Ward 2013) It shows that religious manifestations appear in various forms and expressions which are considered to be in accordance with the needs of the community. (Fitri 2012) 
Mosque and Reproduction of Arab Identity....

\section{Method}

This research discusses mosques and reproduction of Arab identity in Hadrami community in Betawi. This aims to analyze the notion that mosques for Arabs are used to dominate society. This was proven that they accepted the offer and held a religious position in the mosque. To explain this purpose, the writer divides it into four parts; the first part of this study presents a description of the origin of the Hadrami community in Betawi. The second part describes the politicization of religion by the Hadrami community in Betawi so that it made the mosque the center of the Hadrami community activities. In the third part, it reveals the existence of religious contestation in the Hadrami community. And part four contains conclusions from all parts of the writing. This article is an important attempt to understand the process of reproduction of Arab identity carried out by the Hadrami community in Betawi.

This research uses a historical approach to discuss various events by focusing on elements of place, time, object, background and figures of events. (Nata 2000:46) Through this historical approach, it can be known the origin of certain thoughts or opinions and attitudes of a figure, sect or community and the religious stereotype of a group and the attitude of a group to another. In addition, through this historical approach it can also be traced to the origin of a situation where an idea emerges from a figure, and it can be seen that an act and thought of a figure is actually forced by the desires and pressures that arise from himself.

This research uses hermeneutic phenomenology method in interpreting and analyzing data. (Lubis, 2004: 100-146) This refers to Martin Heidegger's theory which explains that phenomenological 
descriptions (Fromme, 2011: 263) are interpretations or hermeneutics. (Heidegger, 1962: 61-62) Hermeneutic phenomenology in this study is used to understand a person's social thinking by giving interpretations of meaning contained in it. (Marriam, 2009: 205) Interpretation is conducted to find a new understanding that mosques are used by Arabs to reproduce Arabic identities, as formulated by Gadamer, (Lubis, 2004: 130) about existing values, for example values that underlinee one's views about individuals, community, social interaction, social problems and others.

\section{Result and Discussion}

\section{A. The Origin of the Hadrami Community in Betawi}

The origin of the Hadrami community in Betawi came from two major races; the first is the race 'Aribah, namely the Southern Arab race, the original Hadramaut of the descendants of Ya'rub bin Qathan bin Hud, which was filled with middle class families and slaves and almost all Hadramaut residents. In the belief of the Arab descendants, the "Aribah was the name of the Hadramaut (descendants of Ya'rub bin Qathan), who was a well-known figure of legend and became the name of the region; and the second is the Muta'aribah race, namely the North Arab race which came from the descendants of Isma'il who is the ancestor the Prophet Muhammad. Muta'aribah race has a habaib group as the highest community group in the Hadramaut. (van den Berg 1989:33)

The two major races were very decisive in the social group in Hadramaut and the Wulaiti 'Alawiyyin group used them in Betawi in the late $18^{\text {th }}$ and early $19^{\text {th }}$ centuries. The division of social groups in Hadramaut or Hadrami tradition was to divide the community with 
Mosque and Reproduction of Arab Identity....

four important groups; first, the sayyid group was the highest because it came from the Muta'aribah race; second, the ethnic group of the non-'Alawiyyin group who entered the race 'Aribah; third, the middle class from the non-'Alawiyyin group who entered the race 'Aribah; fourth, the lowest group consisted of slaves. (van den Berg 1989:47)

The 'Alawiyyin community from the Hadrami in Betawi was the first migrant to form the Arab community in the $18^{\text {th }}$ century. Therefore, they then lead the Arabs both from the "Alawiyyin community and the group from non-Hadrami in Betawi according to the traditions of Hadrami values. The process continued until the Arab community then formed a society that was formally recognized by the government in 1844. (van den Berg 1989:72)

These Arab individuals formed settlement groups in the Betawi area. In forming its identity, (Putra 2013) many of them gathered in Pekojan together with the Moorish community which began to diminish. Although the regulation of ethnic villages (wijkenstelsel) was only implemented by the government in $1818 \mathrm{~m}$, (Lohanda 1994:2) in reality many Hadrami and non-Hadrami people lived side by side with them.

In the late $18^{\text {th }}$ and early $19^{\text {th }}$ century, not all Arabs in Betawi lived in the Pekojan Moorish village, but some lived in other villages such as Luar Batang area, Kampung Tambora, Kampung Petamburan and Kampung Bandan. (Assegaf 1996:93-94) When the shipping business carried out by the Hadrami community increased and grew in the period from 1774 to 1777, (Alatas 2010) the number of Hadrami in Pekojan increased. From the large number of the population, it could be said that around the 1820s the village of Pekojan was filled with Arabs who began to form a "community". With the presence of 
Hadrami with all these dominant social roles, the Moors were slowly eliminated from Pekojan.

The beginning of the $19^{\text {th }}$ century, Pekojan village was known as an Arab village dominated by Hadrami community. So that at that time it could be said that the name Pekojan was no longer synonymous with the Moors, but more identical to the Hadrami Arabs so that it became known as the "Arab village". (Putra 2013)

The identity of Arab individuals in Betawi was known as a religious expert. (Alatas 2010; Aziz 2002:39) The profession provided space for individuals in the Hadrami community to interact in Betawi. There were many Hadrami from 'Alawiyyin who taught Islamic knowledge in Betawi. As a result of this dominative role, the 'Alawiyyins became an important religious symbol in Betawi. Therefore, the 'Alawiyyin community then united to maintain its religious social identity in Betawi. (Aziz 2002:39)

This effort was seen when several 'Alawiyyin leaders then built mosques in Betawi as a dominant center of their religious roles. Among them were Habib Abdurrahman bin 'Alwi Asy-Syatiri who lived in Betawi in 1737 (Kazhim 2013:17) and Habib Husain bin Abu Bakar Alaidrus who died in 1798 in Luar Batang. (van den Berg 1989:105) However, not all of the 'Alawiyyin built mosques in the context of religious teaching activities. Among them, Habib Abdullah bin 'Aqil bin Yahya who lived in Pekojan and returned to Hadramaut in 1825 (Noupal 2008:305) and Habib Abdurrahman bin Abu Bakar alHabsyi who came to Betawi in 1829. (van den Berg 1989:105)

The 'Alawiyyin community had the highest rights in religious teaching according to tradition and religion that applied in Hadramaut, but in reality there were also non-Hadrami community members who 
Mosque and Reproduction of Arab Identity....

taught religion in Betawi. The difference was that 'Alawiyyin people from the Hadrami group if they became religious teachers rarely do trade. This was clearly different from the religious teachers from the non-Hadrami community who became big traders or shipping entrepreneurs.

The teachers of Islamic knowledge from the hadhrami community in the early $19^{\text {th }}$ century in Betawi included a big trader from Egypt named Syaikh Abdurrahman bin Ahmad al-Masri. He came to trade in Palembang, but later moved to Betawi. In Betawi, he later succeeded in buying vast land in Petamburan to establish a mosque and his house in 1800. He was also known as an astronomer, he died in 1847 and was buried behind his mosque in Petamburan. (Azra 2013:318) Another name for the Arab from non-'Alawiyyin in Betawi was an Arab who founded Langgar Tinggi (little mosque) in Pekojan named Syaikh Sa'id bin Salim Naum. He then also converted his house and land in front of the Langgar for religious activities in 1854. Among the Arab community in Betawi, Syaikh Sa'id bin Salim Naum was best known as a wealthy shipping vessel entrepreneur in the early $19^{\text {th }}$ century. (Shahabuddin n.d.)

The interactions carried out by the 'Alawiyyin community with the indigenous people in Betawi have influenced the socioreligious values such as the superiority principles of the Prophet Muhammad descendants and the textuality of the conservative prophetic tradition. (van den Berg 1989:63; Ibrahim 2001:5) On this matter, the social elements of religion formed in Betawi including the norms, systems and behavior at the end of the $18^{\text {th }}$ century and the beginning of the $19^{\text {th }}$ century were very synonymous with the socioreligious identity of the 'Alawiyyin community. (Nottingham 1981:32- 
45) The basic principle formed from the above elements succeeded in making the social identity of the "Alawiyyin community the highest and exclusive in the community. (Algadri 1984:5) Therefore, the conservative and exclusive socio-religious values are then integrated with the community order and system in Betawi.

\section{B. Politicization of Religion by the Hadrami Community in Betawi}

This section uses the term "politicization of religion" which shows the existence of a religious relationship that mixes the values of religious teachings - interpretations of Qurān, Hadīth, even the edicts of ulama - with political issues. (Effendy 2005:12) Even according to Jürgen Habermas, religion increasingly shows its influence in the political space. Religious issues can determine political attitudes in the presidential election and elected regional elections, ratification of laws, regional regulations, even up to the state constitution. (Habermas 1991) Michaella L. Browers states that there is no dichotomy between religion and politics, both legally and theologically. (Browers, 2004) Islam accepts religious pluralism. (Ansor 2016) Likewise in the thesis written by Ayla Gol who states that the real problem is not a debate about Muslims and secularists, but the established relations between religion and politics as in Turkey. (Göl 2009) The politicization of religion carried out by the Hadrami community can be seen in the Pekojan mosque.

The Pekojan Mosque was one of the places used by the Hadrami community to teach and convey religious advice as well as important religious knowledge (Bin Yahyā 1912). The rich Hadrami leaders were very concerned about the construction and maintenance of the Hadrami community's mosque, (Bin Yahyā n.d.) so that the 
Mosque and Reproduction of Arab Identity....

mosque became the pride of the Hadrami community in Betawi. The mosque was inaugurated after Friday prayers on August 10, 1906 by Batavia city council prosecutors namely Raden Mas Prawirodiningrat witnessed by the public. (Anon 1906)

The Pekojan Mosque was used by 'Uthmān bin Yahyā to recite a prayer specifically for the Dutch Queen Wilhelmina in the ceremony of the ascension of the Queen to the throne, after the Friday prayer on 2 September 1898 (Anon 1913b, Anon 1919a). He also shared copies of the prayer to be read during Friday prayers throughout Java and Madura. With this prayer, the Dutch colonial government finally awarded 'Uthmān bin Yahyā as an Order of the Netherlands Lion member on 31 August 1899 (Anon 1899b; Hurgronje 1899; Kaptein 1998).

'Uthmān bin Yahyā firmly justified the prayer he compiled and recited, taking the Islamic concept of friendship, which had a strong foundation in Islamic teachings. He reasoned that the prayer for the queen of Wilhelmina was not only legally permitted, but also important because it was intended as a means of obtaining the good and salvation of life for Muslims. (Bin Yahyā 1898) The prayer he offered attracted some strong reactions from the Hadrami community. Therefore, this prayer on the one hand brought 'Uthmān bin Yaḥyā to get an award from the Netherlands, but on the other hand, it caused him to lose prestige among the Hadrami. (Kaptein 1998)

There were several reasons expressed by 'Uthmān bin Yahyā in reciting prayers to Queen Wilhelmina, first, the government provided protection for Muslims under the rule of the Dutch kingdom. Second, that the government provided freedom for the community to carry out religious activities. Third, the government paid salaries to 
religious leaders. Fourth, the government gave freedom (vrij) to mosque employees and religious teachers for their obligations to the government. Fifth, the government helped to establish a mosque. Sixth, the government helped the landraad in determining the fasting month. (Kaptein 2007; Yaḥyā 1913:14-15)

But the Betawi people saw a special closeness between 'Uthmān bin Yahyāa and the Dutch East Indies government. Therefore, not many Betawi people learned Islamic knowledge to him even though he was recognized by his knowledge. For the Betawi people at that time, an ulama who worked for the government, even though he was a leader, was not regarded as honorable despite his extensive knowledge (Fadli 2011:86-90). 'Uthmān bin Yahyā̄'s closeness with the Dutch East Indies government was considered a spy or someone who sold Islam for his own purposes. (Azra 1995; Steenbrink 1984:136) But this accusation was rejected by Steenbrink who thought that people like 'Uthmān bin Yahyā were ulama who saw Islam in Indonesia as Islam whose teachings were not appropriate. (Steenbrink 1984:136) Steenbrink's argument was based on the fact that almost all the works of 'Uthmān bin Yahyā always criticized the lives of Muslims at that time which were not in accordance with the Shari'a.

Moreover 'Uthmān bin Yahyā was also considered as a person who cooperated with the Dutch government. He reportedly received a sum of money every month for his participation in providing information on the development of Islam in the Dutch East Indies. In fact, he also received a sum of money as a contribution to cover printing costs in his publishing business which was deemed suitable to maintain the political status quo. (Azra 1995; Steenbrink 1984:136) 
Mosque and Reproduction of Arab Identity....

The position as a reference in religious fatwa causing 'Uthmān bin Yahyā to consciously called himself the Betawi mufti. (Yahyā 1898:6) That view did not arise from himself alone, but also arises from the indigenous (Betawi), Arab and government in Betawi. Therefore, he was often asked for information regarding religious social issues related to Arab affairs and Islam by the colonial government. The title "mufti" carried by 'Uthmān bin Yahyā was first written by Snouck Hurgronje in November 1894 published in Het Recht in Nederlandsch-Indie volume LXIII. The title of the mufti was interpreted by Snouck Hurgronje because of the position of 'Uthmān bin Yahyā as the author who always explained the questions and social religious problems that occurred in the community. In a personal statement, "Uthmān bin Yahyā stated that he was a mufti after many called himself as the "Great Betawi Mufti". (Hurgronje 1992:36; Bin Yahyā 1898:6)

With his position as a mufti, 'Uthmān bin Yahyā was above two interests; the interest of the colonial government and Arab interest. (Suminto 1985:161) This position was also often the reason for the Betawi people and the Arabs themselves at that time to discredit him. Several articles in a number of Arabic-language newspapers published in Turkey, Beirut and Egypt, always insinuating his position as a traitor and one who did not care about the fate of fellow Muslims. (Anon 1896, Anon 1899a, Anon 1899c)

Based on the above data it can be said that the mosque is the center of life that can accommodate all forms of social needs and activities, mosques can be one of the identities of a community where the mosque was built. (Ansor, Amri, and Arrauf 2014; Febriani 2004) This is reinforced by Syamsul Kurniawan who stated that the function 
of mosque should not be limited as a place of prayer only. The function of a mosque in its history is far more extensive, than just a place to worship. (Kurniawan 2014) One of them is the politicization of religion carried out by 'Uthmān bin Yahyyā at the Pekojan mosque. This is in accordance with what is revealed by Bassam Tibi, namely an attempt to manipulate religious understanding and knowledge or belief by means of propaganda, indoctrinization and disseminated campaigns and then disseminated to the public domain. (Tibi 2001, 2012)

\section{Religious Contestation in the Hadrami Community in Betawi}

Betawi has its own uniqueness including its similarity to the Islamic tradition in its home country, namely making mosques as a starting place in educating the people. (Makdisi 1990:50-52) For the Betawi community, mosques have more functions, not only a place to worship five times a day, but also a place to study. The situation was demonstrated by the Bataviaasch Niuwsblad newspaper published on August 27, 1898 which reported that mosques were used for various functions such as the social-religious information broadcasting center. (Anon 1898; Bin Yahyā 1894)

In general, at the end of the $19^{\text {th }}$ century, the religious quality of Muslims in the archipelago declined dramatically. At that time there was very rarely an ulama who became a reference to religious matters. This situation is very worrying. (Yahyā 1895:15) Because of that, many people did not learn the knowledge of tauhid (monotheism) and fiqh. Take an example of that the Hadrami community could not distinguish between halal and haram cases. In addition, the Hadrami community did not seek to find a good teacher, (Yahyā n.d.) and only learned from teachers who were less fluent in the pronunciation of 
Mosque and Reproduction of Arab Identity....

hijaiyyah letters. As a result many made mistakes in reciting their prayers, especially in very difficult Arabic recitations. (Yahyā n.d., n.d.) The incorrect reading of the prayers above, in the end made them abandoned their obligations. (Yahyā n.d.)

Based on these conditions, the religious teachers used mosques to teach religion to the community, for example the Arabian headman named Shaikh Mu'allim Ahmad Bahyan, who was proposed to the assistant resident to become an Imam of Arabs in marriage and also to become a teacher in reading the Qurān. (Shahabuddin n.d.:16) Because at the end of the $19^{\text {th }}$ century, there was a decrease in the ability and quality of religious teachers such as knowledge of 'tajwid and Arabic. Many Arab ulama actually had very low religious knowledge and little understanding of the social problems. (Anon 189; Yahyā n.d., n.d.)

Even though they were low in knowledge and did not understand religious matters, they were brave enough to give religious advice and fatwas at the mosque where they were teaching. Therefore, the teaching given by the teachers in the mosque must be adapted to the religious understanding of the Hadrami community, including PanIslamism and modernity.

\section{a. Pan-Islamism}

Pan-Islamism refers to a term that expresses a religious solidarity movement in various Muslim regions which is controlled by the Western colonialism. The movement was pioneered by several figures including Jamal al-Afghani, Muhammad Abdul Wahab, and Muhammad bin Sanusi in the $19^{\text {th }}$ century. (Godhechot 1998:118; Stoddard 1966:50-51, 61-62) The strength of the pan-Islamism movement grew stronger in the eyes of Muslims, when it received support from Sultan Abdul Hamid of the Ottoman Empire. (Anon 
1919b; Federspiel 2001:11; Stoddard 1966:61-62, 65) The purpose of establishing the Pan-Islamism movement is to advance the unity of Muslims. Pan-Islamism leaders urge people to unite and condemn the disunity within the Muslim body (Kaptein 1998, 2014).

The influence of the Pan-Islamism movement according to Snouck Hurgronje had begun to enter the Hadrami community in 1884 through print media (Hurgronje 1897, 1904). The various newspapers referred to by Snouck Hurgronje were newspapers published in Turkey, Syria and Egypt, they were Samarat Al-Funun, Tarabulus, Misbah, Mua'ayyad and Liwa. The various newspapers mentioned above, accor ding to him, had been able and freely read by every Arab, especially those who lived in Betawi and other regions in the archipelago. (Hurgronje 1904) In line with Snouck Hurgronje's statement, 'Uthmān bin Yahyā also stated that newspapers and magazines were part of the active propaganda form of the panIslamism movement. (Yahyyā 1912) The existence of the movement according to him was only seen after the presence of five Turkish General consuls at the end of the $19^{\text {th }}$ century in Betawi. The names of the Turkish consul general in Betawi included Galib Bey in 1897, Kiamil Bey, Amin Bey in 1898, Sadiq Belig Bey and Haji Rasyim Bey. (Hurgronje 1897)

The Turkish consul general in Betawi held propaganda with pan-Islamism ideas especially to the Arab community such as: (1) the equality of the degree of Arabs with Europeans; (2) change of several government legal provisions; (3) liberation of Arabs from government oppression; (4) the welfare of Arabs in the archipelago and the sending of Arab youth in Betawi to Istanbul to study at the expense of the Sultan of Turkey. From this propaganda, the consuls of the Turkish 
Mosque and Reproduction of Arab Identity....

general got sympathy from the Arab community so that they sometimes acted higher than the Arabs. (Hurgronje 1904)

Teachers at the mosque were required to reject pan-Islamism ideas. The main reason was because the fatwas of pan-Islamism figures showed various deviations. The fatwa was taken from the interpretations and theorems of religion at their own will which resulted in the emergence of slanders among the Hadrami community. Among the religious advice and fatwa mentioned were like being allowed to tan meat that was killed by being strangled and beaten, justifying liquor other than wine (khamer) and allowing Hadrami community to wear European hats (borneta) and other European clothing. (Bin Yaḥyā n.d.:2, 4, 6)

'Uthmān bin Yahyyā stated that clothing with a type of suit, hat, cap was a European property; the robe was owned by an Arab; kebaya and stagen on the head (headband) were native clothing (Hurgronje 1904:5-7), although there were indigenous people dressed in robes or turban after returning from the pilgrimage. (Noupal 2008) He stated emphatically that if the Hadrami community exchanged their clothes, they would never even have glory. (Yahyā 1911a, 1911b, 1911c) According to him, the Hadrami community that did "changing their nation's clothes" would only cause shame and expel them from the fortunate and safe group of people. (Hurgronje 1904:2-4)

The use of European and Turkish clothes by the Hadrami community also made various social problems in Betawi such as debate, slander and crime, although according to him many had been overcome. These problems were described by 'Uthmān bin Yaḥyā as happened in 1904, where an Arab young man wearing Turkish clothes pretended to be a new master (bey) and beat a landlord in Menteng. 
For this action, the young man and his father were put in prison for half a month. (Yahyyā 1901)

Snouck Hurgronje also reported the incident in a letter sent to the governor on 12 June 1905. According to Snouck Hurgronje the young man was named Ahmad Ba Junaid and Said Ba Junaid and the son of Bin Sunkar who had just returned from Constantinople (Istanbul). The three of them then boasted their Turkish clothes to the Arab community in Betawi and behaved disrespectfully to the reprimand of the assistant resident of the Betawi police. The resident assistant was named J. Eithoven who rebuked the three of them with a government circular letter dated June 2, 1903 no. 1844 about not getting clothes that were not in accordance with "nationality". Finally they and their parents were fined by the police due to their actions. (Hurgronje 1905)

Taking into account these data, it is not strange if then 'Uthmān bin Yahyā said that pan-Islamism is bid'ah and misleading; in fact, he considered it a major disaster for Muslims. (Noupal 2008, 2014; Yahyā 1911a:10) It is not strange that he did not remain silent in giving an explanation to the Hadrami community about bid'ah and heresy which undermined this Islamic law. Therefore he included the Hadīth of the Prophet who said that "If bid'ah has emerged while the knowledgeable person is silent, then for him the curse of Allah, angels and all humans". (Noupal 2008, 2014; Yahyā 1988:2) This is reinforced by Deliar Noer that people who wear European-style clothing were considered to imitate Europeans, namely Christians and were sometimes also considered to have been infidels. Even more wearing a tie, panty pants and European-style hats, it was very hated 
Mosque and Reproduction of Arab Identity....

by the people who consider the use of ties, trousers and caps were prohibited. (Noer 1982:9)

Besides that, pan-Islamism is part of Wahabi propaganda and Syi'ah Rafidah. (Yahyā 1912) Whereas the Hadrami community strongly refused Wahhabism and Syi'ah Rafidah, (Noupal 2008, 2014; Yahyā 1988:4) because it was very contrary to Hadrami religious values. (Yaḥyā 1900:15)

Wahhabis were considered contrary to Hadrami religious values because they considered the infidels of those who carried out tawassul and istigāsah, infideling people who respected Wali and came to their graves, destroying the dome of the grave, infideling those who believed in the karomah of the saints and considered it shirk, forbid pilgrimage to the Prophet's grave and pilgrimage in general which they considered sinful, forbid reading the book Dalā'il al-Khairāt and ordering to be burned, prohibiting reading the book Rāudu al-Rāyyāhīn and naming it Ardu al-Syayâtîn. (Noupal 2008, 2014; Yaḥyā 1988:14)

In addition, the Wahhabis also assumed that the Prophets and Wali (guardians) of Allah if they had died, they would not have a noble position again. The Wahabis even said that "my stick is more useful than the Prophet Muhammad". In addition they assumed that people who make pilgrimages to the guardian's grave were the same as those who worshiped idols. They also killed many ulama in Makkah and Madinah and killed people who did not want to come with them. In fact they were very clever confusing the arguments of the Qurān by bringing verses that dealt with infidels but were dropped on Muslims. (Noupal 2008, 2014; Yahyā 1911b:24)

As for the movement of Syi'ah Rafidah, they were misled because they berated the companions of the Prophet Muhammad. 
Whereas the Hadrami community believes in the virtues (afdaliyyah) and justice ('adālah) of the Companions of the Prophet. In addition, it is also obligatory to respect and love, and not to insult them. (Noupal 2008, 2014; Yahyā 1988:75) The person who berated the Prophet's companions is considered as a great sinner. (Noupal 2008, 2014)

Therefore, the Hadrami community was obliged to study religion or other useful knowledge in life. If the 'Alawiyyin and the Arabs were ignorant for not learning, then they would fall into wrong association and cause various disobedience which ultimately would make it difficult for them to get a job in supporting their family. (Yahyā 1894, 1899a, 1899b) Because by learning that, they would have knowledge that could improve their behavior for the safety of the danger of the world and the hereafter. (Hurgronje 1897:20; Yahyā 1894) Therefore, the children of the Hadrami were required to study the Qur'anic knowledge such as tajwid, tartil and memorization of the book Riyāa al-Sibyān Mandhūmah by Shaikh Ahmad Bahdhib. Apart from religion, they also needed to learn Arabic, arithmetic and writing (Yahyā 1909:6). In addition they also studied books such as Risālah Safinah al-Najāh karya Salim bin Sumair, Mu'allim karya Habib Ahmad bin Zain dan kitab-kitab lainnya seperti Mukhtașar Abī Faḍl, Bidāyah al-Hidāyah, Hilyah al-Banīn Wa al-Banāt, 'Umdah Sālik, Fath al-Mu'īn, Ihyā 'Ulūm al-Dīn dan Mulhah al-I 'rāb serta Jurmiyah. (Yahyā 1909:7) Therefore, the children of the Hadrami are required to study the Qur'anic knowledge such as tajwid, tartil and memorization of the book Riyād al-Ṣibyān Mandhūmah by Shaikh Ahmad Bahdhib. Apart from religion, they also need to learn Arabic, arithmetic and writing. (Yahyā 1909:6) In addition they also studied books such as Risālah Safīnah al-Najāh by Salim bin Sumair, Mu'allim by Habib 
Mosque and Reproduction of Arab Identity....

Ahmad bin Zain and other books such as Mukhtașar Ab̄̄ Faḍl, Bidāyah al-Hidāyah, Ḥilyah al-Banīn Wa al-Banāt, 'Umdah Sālik, Fatḥ alMu'īn, Iḥyā' Ulūm al-Dīn and Mulah al-I'rāb and Jurmiyah. (Yaḥyā 1909:7) By studying those books, they could avoid concept that is contrary to the 'Alawiyyin religion, for example Wahabi and Syi'ah.

In addition to contradicting Hadrami's religious values, according to 'Uthmān bin Yahyā, pan-Islamism also brought rifts to the Hadrami community. (Yahyā 1901) The form of rift in the Hadrami community was described by 'Uthmān bin Yahyā at the farewell at the house of Habib Abdullah bin Husayn Alaidrus in Pekojan after Friday prayers on the first week of March 1901. The farewell ceremony was held to honor the departure of 100 Sädah from 'Alawiyyin people to Hadramaut led by Habib Abdullah bin Abu Bakar Alattas and Habib Ahmad bin Taha Assegaf. In the event, the host's welcoming speech to the guests was represented to Habib Hasan bin Shahab. The speech turned out to be the writing of 'Uthmān bin Yahyā, whose contents invited the audience to study religion to 'Uthmān bin Yahyā and prejudiced him. For the reading of the speech, many of the Hadrami people who were present immediately cried and received the distribution of the printed sheets with feelings of emotion. (Yahyā 1901)

In 1909, 'Uthmān bin Yahyā asserted that the various newspapers had succeeded in making cracks and hostilities in the form of incitement and hatred throughout the country. The hostility formed by them according to 'Uthmān bin Yahyyā intentionally pitted himself against various problems from the Arab community. He saw that these various problems were a response to their disagreement with his prayer recitation during the coronation of Queen Wilhelmina on September 2, 
1897. Even though he stated that the actual prayer he had compiled in 1896 for the Queen of the Netherlands was based on worldly and religion context (Kaptein 1998; Ryad 2009:4; Yahyā 1900:15).

Some Dutch-language newspapers such as Algemeen Handelsblad also publish what was stated by 'Uthmān bin Yạ̣yā above. In the news it said that there were three Arabs who attacked 'Uthmān bin Yaḥyā in a newspaper saying 'Uthmān bin Yaḥyā was a high-level conservative and orthodox person. This opinion was raised because he opposed Arabs who used European clothing. (Anon 1913a)

Along with the conflict between the elderly and the young in the Hadrami community, 'Uthmān bin Yahyā is the last stronghold of upholding traditional and religious values in the Hadrami community in the first 10 years of the 20th century. He said that after the entry of pan-Islamism, he saw a movement that opposed tradition and religion launched by a group within the Hadrami community. He saw that the movement was increasingly visible when support for young groups was getting stronger. When the conflict between the old and young groups grew, 'Uthmān bin Yahyā said that their step in inviting the religious teachers was their attempt to attack him. Those teachers often mocked his way of teaching and taught the Arabs in the mosque to hate the Prophet's ahlul bait and demonize others. (Yahyā 1906:23-24)

'Uthmān bin Yahȳā rejected pan-Islamism but he was accommodative to colonialism, because of the aim of pan-Islamism was to free Muslims from colonialism. Pan-Islamism leaders appealed to the authorities and all elements of the Hadrami community to unite so that Muslims could be free from colonialism. (Burhanudin 2014, 2015) 
Mosque and Reproduction of Arab Identity....

Besides supporting both non-Muslim rules in Muslim lands, and the Hadrami community, 'Uthmān bin Yahyā also tended to ignore political matters, they ignored Dutch oppression of indigenous Muslims as long as their interests were not in danger (Azra 1995; van den Berg 1989:114). Thus pan-Islamism turned out to be more developed in the indigenous community compared to the Hadrami community. The Hadrami community at that time did not show a fanatical attitude, nor did they put hatred on Europeans because of religious differences, they greatly appreciated that in the Dutch colonies, the institutions of Islamic law were maintained as well as possible. (van den Berg 1989:114)

'Uthmān bin Yahyā emphasized harmonious relations with the Dutch government based on maintaining security and the right to do prayers. This attitude was owned by him because he was a shariaoriented ulama. (Fanani 2011) He unceasingly showed that people maight remain loyal to the colonial government in the Archipelago while practicing Islamic worship. (van den Berg 1989:106)

'Uthmān bin Yahyā sincerely hoped that the Dutch government would still not interfere in religious affairs, especially not preventing Muslims from practicing their religion. He also thanked the government for giving salaries to religious judges, assisting the leaders and teachers, giving holidays to the religious court in the fasting month and helping to establish mosques. Therefore, he advised the Hadrami community to thank the government by carrying out religious orders and not violating government regulations. (Yahyā 1913:7-9) However, after 'Uthmān bin Yahyā died, the Dutch government began to interfere in religious affairs, One of which was the removal of the title of mufti. (Steenbrink 1984:138) 
The data shows that the main motivation of 'Uthmān bin Yahyā rejected pan-Islamism was economy and access to power. Fanani stated that this was due to 'Uthmān bin Yahyaa being part of the Muslims who realized that they were living under the control of a nonMuslim government. On the other hand, 'Uthmān bin Yahyyā had an interest in maintaining order (the cosmos) which was then carried out by the Dutch. (Fanani 2011)

\section{b. Modernity}

The Hadrami community in Betawi in the beginning of the 20th century entered a modern social-religious life (Yaḥyā 1909:6). 'Uthmān bin Yahyyā described modernity as an age decoration or satanic deception, as seen in the formation of Arab children similar to Europeans. According to him the resemblance was seen in the elements of educational equipment such as the madrasa office, subjects, teaching tools and clothes worn by their teachers and students. (Yahyyā 1909:10-11) According to Sunarto As, modernity is characterized by a very rapid process of change from a primitive society to a society of civilizations. (As 2013)

Modernism spread to the Hadrami community, both in the central and peripheral areas. This enthusiasm was widely accepted by those who saw how Islam was far behind the Western world. (Noupal 2008, 2013) 'Uthmān bin Yahyā mentioned that the influence of modernism that developed in the mosque was allegedly had brought a lot of bid'ah which damaged religion. Some of the mistakes were that they dared to interpret the Qurān with ignorance without knowing the conditions needed in interpretation. They were more likely to use their own minds. People who did bid'ah also claimed to be able to give 
Mosque and Reproduction of Arab Identity....

ijtihad or claimed to be an absolute ijtihad expert who could take law from the Qurān. Besides that they were good at narrating false Hadīth and canceling the true Hadith. And greater than that, they were clever to confuse all problems with their tongues by saying arguments to fool the ignorant and dare to curse and denounce the ulamas. (Yahyā 1911a, $1911 b, 1911 c)$

Hadrami community viewed that Islamic law could not be changed anymore. For them, the reinterpretation of the Qurān could not be done because it was considered to have violated the principles agreed upon by the previous ulama. To take a direct law from the Qurān, a person would not be able to do it because there were severe terms and conditions. (Noupal 2013) In fact, according to Joris in his research stating that aspects of modernity range from secular characteristics. (Van Eijnatten et al. 2013) Religious teachers in mosques must not interpret or took laws from the Qurān especially those that did not have the requirements of interpretation or ijtihad. He cited the authority of the well-known commentary ulama, al-Suttī, in al-Itqān that "The interpretation was determined by the ulama commentary". (Yahyyā, n.d .: 122)

In addition to rejecting the reinterpretation of the Qurān, the Hadrami community also rejected calls for ijtihad which were the main thing for modernists. This appeal was motivated by the idea that Islam was not a static but dynamic religion. It was also because Islamic law (fiqh) was only the result of the ulama's thoughts on a problem whose case with modern times was not always the same. To provide legal decisions for the community in accordance with the circumstances, ijtihad was very necessary. (Noupal 2013) 
For the Hadrami community, ijtihad could violate the religious principles of the Hadrami they had embraced since a long time ago. They believed that ijtihad could not be done unless the conditions fulfilled. They also believed that someone would no longer be able to master 15 branches of science that were absolutely necessary in the process of ijtihad. In other words, ijtihad could not be done again; the door to ijtihad has been closed. (Noupal 2014) Furthermore, according to the Hadrami community, "we must not be different from the previous ulama. We also must not do ijtihad without the agreed conditions, we may not even act with our own minds that are different from the ulama from ahlu sunnah". (Yahyā 1911a:6)

Seeing the severity of the requirements needed in ijtihad, the Hadrami community considered that ulamas like Imām al-Suyuti alone did not dare to recognize themselves as mujtahid, either as absolute mujtahid or mujtahid nasb. In fact, the quality and excellence in the scientific field needed not be doubted. (Yahyā, n.d .: 14) The call for ijtihad was regarded as false and misguided. (Yahyyā 1911a:7)

The principles of ijtihad which were agreed upon by the ulamas since the old days that there were no absolute mujtahid ulama after the sect (mazhab) imam of passed away. There were also no more people who were capable of mastering the 15 branches of knowledge needed for jihad, even if he is a smart Arab. 'Uthmān bin Yahyā doubted that all branches of knowledge could be mastered by someone who charged himself as a mujtahid. (Yahyā 1907a, 1907b)

The teaching given by the modernists in the Betawi mosque caused many Arab children to leave to study the books of the 'Alawiyyīn salaf. As a result many Arab children had several behaviors such as greed, indictment, ijtihad, lying and denouncing 
Mosque and Reproduction of Arab Identity....

taklid. (Yahyā 1909:10-11) Therefore, the Hadrami community should continue to follow the steps of their ancestors in the previous Hadramaut so as not to become a group that loses and despairs to their future lives. (Yahyā 1909:12) Therefore, religious teachers at the mosque provided benefits for the behavior of the Hadrami community in Betawi. So that they could unite with the Hadrami community to work on something useful for the homeland and its next generation. (Yaḥyā 1907a:3)

'Uthmān bin Yahyā also condemned the efforts of some Hadrami who followed the teachings of the modernists because the movement was considered to be against tradition and Hadrami religion (1896 n.d.;Yahyā 1911b). For him, the glory of the family in the Hadrami community during the period of modernity could be visible when the next generation would continue to imitate the behavior of their ancestors (jid) as proof of the sanctity of their ancestors. (Yahyā 1899a:28-30)

On this basis, 'Uthmān bin Yahyā stated that it was very unethical if many of the children of the respected and rich families of the Hadrami community studied religion in mosques taught by modernists. According to him, it would be better for them to send children to the Wadi Anwar religious education institution which proved to have more good (barakah) and be a recommendation from the previous salaf ulama. (Yahyā 1909:4)

Because of this statement, 'Uthmān bin Yahyyā wanted the establishment of the madrasa to anticipate the dangers of educational modernity that threatened the Arab generations. (Anon 1889) With the establishment of the madrasa, he could teach his knowledge so that all the knowledge he had could be taught to them. (Yahyā 1904a, 1904b) 
Whereas according to Zaprulkhan in his research that modernity itself refers more to a handful or group of intellectual elites who try to overcome the challenges of modernity trying to make progress or change. (Zaprulkhan 2014)

Seeing that social reality, 'Uthmān bin Yahyā reminded that recitation in the Pekojan mosque should be maintained, because it did not use foreigners' clothing, equipment, and teaching. In addition to the recitation in the Pekojan mosque, the teachings of the ancestral books of the 'Alawiyyin could be taught to Arab children in accordance with ancestral ideals in the Hadrami community tradition and religion. (Yạ̣yā 1909:4, 1911c, n.d.)

Based on the above data it can be said that the mosque is the center of life that can accommodate all forms of social needs and activities, mosques can be one of the identities of a community where the mosque was built. (Febriani 2004) This is reinforced by Syamsul Kurniawan who stated that the function of the mosque should not be limited to just a place of prayer, given the fact that the function of the mosque in its history is far more extensive, than just a place of worship. (Kurniawan 2014) This can be seen from the Hadrami community who built mosques in Betawi as the center of their religious identity, (Anon 1898) in the form of their rejection of panIslamism and also their resistance to modernity.

\section{Discussion}

The Pekojan mosque used by 'Uthmān bin Yahyā to recite a prayer specifically for the Dutch Queen Wilhelmina on Friday 2 September 1898. In fact, he also shared copies of the prayer to be read on Friday prayers throughout Java and Madura. From here, it could be 
Mosque and Reproduction of Arab Identity....

seen that the function of the mosque was not only as a place of worship, but also for the politicization of religion carried out by 'Uthmān bin Yahyyā in the Pekojan mosque. Namely by means of propaganda, indoctrination and disseminated campaigns were then socialized to the public area to manipulate religious understanding and belief.

The mosque is also the first place to educate people. But it was used by the Hadrami community to reproduce Hadrami religious identity. This was evidenced by the refusal of religious teachers to teach pan-Islamism and modernism in the Betawi mosque because it was contrary to the religious understanding of the Hadrami community. The main reason was because the fatwas of pan-Islamism figures taught a variety of heresies such as being allowed to tan meat killed by strangling and beating, justifying liquor other than wine (khamer) whose law is doubtful and allowing Hadrami communities to wear European clothing. Besides that, pan-Islamism was part of Wahabi propaganda and Syi'ah Rafidah which was very contrary to Hadrami religious values.

Besides that the Hadrami community also rejected the notion of modernity, such as the reinterpretation of the Qurān, the call to do ijtihad which was the main thing for the modernists, even threatening the Arab generation. Because the knowledge given by the modernists in the Betawi mosque would cause many Arab children to abandon learning the books of the 'Alawiyyin salaf which were feared against the traditions and religion of the Hadrami. That the glory of the family in the Hadrami community in the time of modernity could be seen when the next generation continues to imitate the behavior of their 
ancestors (jid). The evidence of the sanctity of their ancestors could be done by reading the books of the 'Alawiyyin salaf.

\section{Conclusion}

This research provides the conclusion that the mosque was used by the Hadrami community to reproduce Arab identity. This could be seen from the mosque which was the center of life of the community and was accommodated to fulfill all forms of needs and social activities, thus the mosque became the identity of the Hadrami community.

The article showed an essential function of a mosque to preserve and redefine the Hadrami social identity in encountering a rapid social challenge. It also found a significant position of a mosque in forming and consolidating the Hadrami's political interests as a response to contemporary dynamics such as dealing with the emergence of pan-Islamism and modern challenges. It was through mosque that Sayyid 'Uthmān bin Yahyā not only succeeded in mobilizing resistance against the idea of pan-Islamism and modernity but also strengthened their social status against the Dutch.

\section{References}

(1896). "Niewsblaad Voor Den Boekhandel, No 99, December 11."

Alatas, Ismail Fajrie. (2010). "Menjadi Arab: Komunitas Hadrami, Ilmu Pengetahuan, Kolonial \& Etnisitas." in Orang Arab di Nusantara. Jakarta: Komunitas Bambu.

Albernaz, Ami. (2011). "Study Examines Link Between Poverty \& Mental Illness", New England Psychologist." New England 
Mosque and Reproduction of Arab Identity....

Psychologist 8(11).

Algadri, Hamid. (1984). C. Snouck Hurgronje: Politik Belanda Terhadap Islam Dan Keturunan Arab. Jakarta: Penerbit Sinar Harapan.

Algadri, Hamid. (1996). Islam Dan Keturunan Arab Dalam Pemberontakan Melawan Belanda. Bandung: Mizan.

Anon. (1889). "De Tijd, Februari 11."

Anon. (1895). “De Locomotief." February 9.

Anon. (1896). “Al-Muayyad.” February 12.

Anon. (1898). “Bataviaasch Nieuwsblad.” August 17.

Anon. (1899a). "Al-Ma'lumat 146th, 150th, 151th Edition."

Anon. (1899b). Missive Gouvernements Secretaris (MGS).

Anon. (1899c). "Thamarât Al-Funûn 1255th Edition."

Anon. (1906). "Van Den Dag.” Het Niews, August 16.

Anon. (1913a). "Algemeen Handelsblad, April 3.”

Anon. (1913b). "Pemberita Betawi.” January 21.

Anon. (1919a). "De Telegraff." January 3.

Anon. (1919b). “Oetoesan Melajoe, May 22.”

Ansor, Muhammad. (2016). “"Menjadi Seperti Beragama Lain': Jilbab

Dan Identitas Hibrid Mahasiswi Kristen Aceh." Penamas 29(1):11-30.

Ansor, Muhammad, Yaser Amri, and Ismail Fahami Arrauf. (2014). "Piety on Contestation: Ethnography on Puritan and Traditionalist Muslim in Aceh Tamiang." Alqalam 31(2):305-33.

As, A. Sunarto. (2013). "Paradigma Nahdlatul 'Ulama Terhadap Modernisasi." Jurnal Sosiologi Islam 3(2).

Assegaf, Muhammad Syamsu. (1996). Ulama Pembawa Islam Di Indonesia Dan Sekitarnya. Jakarta: Penerbit Lentera.

asy-Syatiri, Habib Yusuf Ali. (2008). Kampung Bandan: Masjid AlMukaramah Dan Makam Keramat 3 Habib. Jakarta.

Aziz, Abdul. (2002). Islam Dan Masyarakat Betawi. Jakarta: Logos Wacana Ilmu. 
Azra, Azyumardi. (1995). "Hadrāmī Scholars in the Malay-Indonesian Diaspora: A Preliminary Study of Sayyid 'Uthmān." Studia Islamika 2(2).

Azra, Azyumardi. (2013). Jaringan Ulama Timur Tengah Dan Kepulauan Nusantara Abad XVII Dan XVIII. Jakarta: Kencana.

van den Berg, Lodewijk Willem Christiaan. (1989). Hadramaut Dan Koloni Arab Di Nusantara. Jakarta: INIS.

Berland, Leema, Rebecca Steingut, and Pat Ko. (2014). "High School Student Perceptions of the Utility of the Engineering Design Process: Creating Opportunities to Engage in Engineering Practices and Apply Math and Science Content." Journal of Science Education and Technology 23(6):705-20.

Burhanudin, Jajat. (2014). "The Dutch Colonial Policy on Islam: Reading the Intellectual Journey of Snouck Hurgronje." $A l$ Jami'ah: Journal of Islamic Studies 52(1):25.

Burhanudin, Jajat. (2015). "Islam Dan Kolonialisme: Sayyid Usman Dan Islam Di Indonesia Masa Penjajahan." Studia Islamika 22(1):185-208.

Effendy, Bahtiar. (2005). Jalan Tengah Politik Islam: Kaitan Islam, Demokrasi Dan Negara Yang Tidak Mudah. Jakarta: Ushul Press.

Van Eijnatten, Joris, Ed Jonker, Willemijn Ruberg, and Joes Segal. (2013). "Shaping the Discourse on Modernity." International Journal for History, Culture and Modernity 1(1):3-20.

Fadli, Ahmad. (2011). Ulama Betawi: Studi Tentang Jaringan Ulama Betawi Dan Kontribusinya Terhadap Perkembangan Islam Abad Ke-19 Dan 20. Jakarta: Manhalun Nasyi-in Press.

Fanani, Ahmad Fuad. (2011). "Fikih Antar Umat Beragama Dalam Pemikiran Sayyid 'Uthmân Bin 'Abdullah Bin 'Aqîl Bin Yahyâ Al-'Alawî.” UIN Sunan Ampel Surabaya.

Febriani, Nur Arfiyah. (2004). "Masjid Dalam Pelestarian Seni Bangunan Islam Di Mesir." Ibda': Jurnal Kebudayaan Islam 12(1):62-71.

Federspiel, Howard M. (2001). Islam And Ideology In The Emerging Indonesian State: The Persatuan Islam (Persis) 1923 - 1957. Leiden, Boston, Koln: Brill.

Fitri, Agus Zaenul. (2012). "Pola Interaksi Harmonis Antara Mitos, 
Mosque and Reproduction of Arab Identity....

Sakral, Dan Kearifan Lokal Masyarakat Pasuruan.” El-Harakah 14(1):1-17.

Godhechot, Jacqeues. (1998). Revolusi Di Dunia Barat (1770-1799). Yogyakarta: Gadjah Mada University Press.

Göl, Ayla. (2009). "The Identity of Turkey: Muslim and Secular." Third World Quarterly 30(4):795-811.

Habermas, Jurgen. (1991). The Structural Transformation of the Public Sphere: An Inquiry into a Category of Bourgeois Society. Cambridge, Massachussets, and London: The MIT Press.

Heiss, Johann, and Martin Slama. (2010). "Genealogical Avenues, Long-Distance Flows and Social Hierarchy: Hadramī Migrants in the Indonesian Diaspora." Anthropology of the Middle East 5(1):34-53.

Heuken, S. J. Adolf. (2003). Tempat-Tempat Bersejarah Di Jakarta. Jakarta: Yayasan Cipta Loka Caraka.

Hurgronje, C. Snouck. (1897). Letter to the Governor General on December 8.

Hurgronje, C. Snouck. (1899). Letter to MJ. De Goeje. Universiteitsbibliotheek Leiden.

Hurgronje, C. Snouck. (1904). Letter to the Governor General on July 28.

Hurgronje, C. Snouck. (1905). Letter Snouck Hurgronje Juli 12.

Hurgronje, C. Snouck. (1992). Kumpulan Karangan Snouck Hurgronje $I V$. Jakarta: INIS.

Ibrahim, Umar. (2001). Thariqah 'Alawiyah: Napak Tilas Dan Studi Kiritis Atas Sosok Dan Pemikiran Allamah Sayyid 'Abdullah AlHaddadd Tokok Sufi Abad Ke-17. Bandung: Mizan.

Jonge, Huub de. (1997). "Dutch Colonial Policy Pertaining to Hadhrami Immigrants." Pp. 94-111 in Hadhrami Traders, Scholars and Statesmen in the Indian Ocean, 1750s-1960s, edited by U. Freitag and W. Clarence-Smith. Leiden,New York, Köln: Brill.

Kaptein, Nico J. G. (1998). "The Sayyid and the Queen: Sayyid 'Uthman on Queen Wilhelmina's Inauguration on the Throne of the Netherlands in 1898." Journal of Islamic Studies 9(2):158-77.

Kaptein, Nico J. G. (2007). "Grateful to the Dutch Government: 110 VOL. 9 NO. 1 JUNE 2020 
Sayyid "Uthman and Sarekat Islam in 1913." Pp. 98-116 in Islamic Legitimacy in a Plural Asia, edited by A. Reid and M. Gilsenan. London and New York: Routledge.

Kaptein, Nico J. G. (2014). Islam, Colonialism and the Modern Age in the Netherlands East Indies: A Biography of Sayyid 'Uthman (1822 - 1914). Leiden: Brill.

Kazhim, Musa. (2013). "Sekapur Sirih Sejarah 'Alawiyin Dan Perannya Dalam Dakwah Damai Di Nusantara: Sebuah Kompilasi Bahan." in Peran Dakwah Damai Habaib/Alawiyin di Nusantara, edited by M. Alie. Yogyakarta: Rausyan Fikr.

Kurniawan, Syamsul. (2014). "Masjid Dalam Lintasan Sejarah Umat Islam.” Jurnal Khatulistiwa 4(2):169-84.

Lohanda, Mona. (1994). The Kapitan Cina of Batavia 1837-1942. Jakarta: Djambatan.

Makdisi, George. (1990). The Rise of Humanism in Classical Islam and the Christian West; with Special Reference to Scholaticism. Edinburgh: Edinburgh University Press.

Mukani. (2017). "Pemikiran Pendidikan Islam Perspektif KH. M. Hasyim Asy'ari." Jurnal Pendidikan Agama Islam 1(1):133-52.

Murti, A. R. (2016). "Mengenal Al-Habib Husein Bin Abu Bakar Alaydrus." Sindo News, May 7.

Nata, Abuddin. (2000). Metodologi Studi Islam. Depok: Rajawali Pers.

Noer, Deliar. (1982). Gerakan Modern Islam Di Indonesia 1900-1942. Jakarta: LP3ES.

Nottingham, Elizabeth K. (1981). Religion: A Sociological View. Amazon: University Press of America.

Noupal, Muhammad. (2008). "Pemikiran Keagamaan Sayyid Uthman Bin Yahya: Respon Dan Kritik Terhadap Kondisi Sosial Keagamaan Di Indonesia.” UIN Syarif Hidayatullah Jakarta.

Noupal, Muhammad. (2013). "Kritik Sayyid Utsman Bin Yahya Terhadap Gerakan Pembaharuan Islam Di Indonesia: Studi Sejarah Islam Di Indonesia Abad 19 Dan Awal Abad 20.” Jurnal Ilmu Agama 14(2):77-98.

Noupal, Muhammad. (2014). "Kritik Sayyid Utsman Bin Yahya Terhadap Pemikiran Pembaharuan Islam: Studi Sejarah Sosial Intelektual Islam Di Indonesia.” Intizar 20(1). 
Mosque and Reproduction of Arab Identity....

van Oudenhoven, Jan Pieter, and Colleen Ward. (2013). "Fading Majority Cultures: The Implications of Transnationalism and Demographic Changes for Immigrant Acculturation." Journal of Community \& Applied Social Psychology 23(2):81-97.

Putra, Heddy Shri Ahimsha. (2013). "Budaya Bangsa, Jati Diri Dan Integrasi Nasional: Sebuah Teori." Jurnal Sejarah Dan Nilai Budaya Jejak Nusantara 1(1).

Ryad, Umar. (2009). Islamic Reformism and Christiany: A Critical Reading of The Works of Muhammad Rasyid Rida and His Associates (1898-1935). Leiden: Brill.

Shahab, Alwi. (2004). Saudagar Baghdad Dari Batavia. Jakarta: Shahab, Alwi.

Shahabuddin, Abu Bakar bin Ali bin Abu Bakar. n.d. Riḥlah Al-Asfar.

Steenbrink, Karel. (1984). Beberapa Aspek Tentang Islam Di Indoensia Abad Ke-19. Jakarta: Bulan Bintang.

Stoddard, Lothrop. (1966). Dunia Baru Islam. Jakarta.

Suminto, Aqib. (1985). Politik Islam Hindia Belanda. Jakarta: LP3ES.

Tibi, Bassam. (2001). Islam between Culture and Politics. New York: Palgrave Macmillan.

Tibi, Bassam. (2012). Islamism and Islam. New Haven and London: Yale University Press.

Yahyā, 'Uthmān bin. (1894). Ini Jadwal Bernama Cahaya Bulan. Indonesia: National Library of the Republic of Indonesia.

Yahyā, 'Uthmān bin. (1895). Taftīh Al-Muqlatain Wa Tabȳ̄n AlMafsadatain. Betawi: 'Uthmān bin Yahyā Publishing.

Yahyā, 'Uthmān bin. (1898). Mas'ilah Fì Al-Du'à' Li Ghayr AlMuslim Wahuwa Walīy Al-Amr Fī Buldān Allat̄̄ Fīhā AlMuslimūn. Betawi: 'Uthmān bin Yaḥyā Publishing.

Yahyyā, 'Uthmān bin. (1899a). Lampoe Bertjahaja Mengatakan Perihal Doewa Perangai Manoesia. Betawi: 'Uthmān bin Yahyā Publishing.

Yahyā, 'Uthmān bin. (1899b). Risalah Dua Ilmu. Betawi: 'Uthmān bin Yahyā Publishing.

Yahyā, 'Uthmān bin. (1900). Sadd Al-Bāb 'An Znann Al-Sū Wa AlIghtirāb. Betawi: 'Uthmān bin Yahyā Publishing.

112 VOL. 9 NO. 1 JUNE 2020 
Yaḥyā, 'Uthmān bin. (1901). Letter to Snouck Hurgronje. Universiteitsbibliotheek Leiden.

Yaḥyā, 'Uthmān bin. (1904a). Al-I'lān Bi Al-Nașīhah Al-Mațlūbah; Pernyataan Dengan Nasikha Yang Terminta. Betawi: Uthmān bin Yahyā Publishing.

Yahyā, 'Uthmān bin. (1904b). Ini Buku Kecil Buat Menyatakan Pertegasan Hukum Adat Negeri Yang Bersamaan Pada Pertengahan Hukum Agama Islam Atas Orang Dengan Memakai Pakaian Lain Bangsanya Adanya. Betawi: Uth.

Yahyāa, 'Uthmān bin. (1906). Kelakuan Terpuji Bagi Guru Mengaji. Betawi: Uthmān bin Yahyyā Publishing.

Yaḥyā, 'Uthmān bin. (1907a). 'Ain Al-Haqq Wa Faṣl Al-Khitâab F̄̄ Ikhrāj Al-Munkhaniqah Wa Al-Mauqūdah 'An Hill Ta'Ām Ahl AlKitāb. Betawi: Uthmān bin Yaḥyā Publishing.

Yaḥyā, 'Uthmān bin. (1907b). Al-Nubdhat Al-Lațīfah Fī Al-Nașīhaḥ Al-Munīfah. Betawi: Uthmān bin Yahyyā Publishing.

Yahyyā, 'Uthmān bin. (1909). Jam' Al-Nafā'is Litaḥsīn Al-Madāris. Betawi: 'Uthmān bin Yahyyā Publishing.

Yahȳā, 'Uthmān bin. (1911a). Nasehat Yang Bermula. Betawi: 'Uthmān bin Yahyyā Publishing.

Yaḥyā, 'Uthmān bin. (1911b). Salāmah Al-Muslimīn Min Al-Ibtid̄̄' F̄̄ Al-Dīn. Betawi: 'Uthmān bin Yahyā Publishing.

Yaḥyā, 'Uthmān bin. (1911c). Tarīqah Al-Salāmah Min Al-Khusrān Wa Al-Nadāmah. Betawi: 'Uthmān bin Yahyā Publishing.

Yaḥyā, 'Uthmān bin. (1912). Letter to Snouck Hurgronje. Universiteitsbibliotheek Leiden.

Yaḥyā, 'Uthmān bin. (1913). Sinar Istirlam. Betawi: 'Uthmān bin Yahyaā Publishing.

Yaḥyā, 'Uthmān bin. (1988). I'ānat Al-Mustarshidīn 'Alā Ijtināb AlBidā'i Wa Al-Dìn. Betawi: Uthmān bin Yahyaā Publishing.

Yahyāa, 'Uthmān bin. n.d. Faqād Ijtā'rai Jamāa'ah Min Wujūh Al- 'Arab Wahim Sayad'u Sahmit Tahta Hādhā Al-Masțūr Ba'da Ma AlTadhkar. Universiteitsbibliotheek Leiden.

Yaḥyā, 'Uthmān bin. n.d. Ini Jadwal Menyatakan Perihal Segala Kesalahan Di Dalam Perkara Membaca Al-Fatihah. National 
Mosque and Reproduction of Arab Identity....

Library of the Republic of Indonesia.

Yahyā, 'Uthmān bin. n.d. Ini Jadwal Sembahyang Dirupakannya Seperti Suatu Pohon Yang Ada Buahnya. Indonesia: National Library of the Republic of Indonesia.

Yạ̣yā, 'Uthmān bin. n.d. Jadwal Tajwid. Indonesia: National Library of the Republic of Indonesia.

Yahyā, 'Uthmān bin. n.d. Perihal Kumpul Uang Buat Bikin (Sinuman?). Universiteitsbibliotheek Leiden.

Zaprulkhan. (2014). "Selubung Ideologis Kaum Puritan Perspektif Khaled Abou Ei Fadl." Analisis 14(1). 